\title{
The First World War: The Neutral Ally
}

In the afternoon of Saturday 5 May 1917, the 19-year-old Fredrik W. Ilboe was feeding the engine of the Bergen-owned steamer DS Nydal with coal, as part of the black gang. He had 11 silk stockings on his left foot-luxury goods from the United States were valuable currency in a depraved Europe, and Fredrik had come across a box full of them. When the sight of an empty lifeboat a couple of hours earlier had suggested that there might be German submarines in the area, he had started to put on the stockings, the better to save them. ${ }^{1}$

Before Fredrik had managed to put the remaining 11 stockings on his right foot, there was a muffled bang that reminded him of a powder charge. Although the first German bombs were way off their target, the attacks got gradually closer, and Fredrik and his shipmates were told to abandon ship. He ran back to his quarters, picked up his best suit, the watch he had been given for his confirmation and a box of letters from home, before jumping into the lifeboat, where he landed awkwardly on the captain's lap.

\footnotetext{
${ }^{1}$ Based on the recollection in Ilboe $(1970,53-62)$ and the report from the maritime inquiry in Sjøforklaringer over norske skibes krigsforlis, 1914-1918. B. 2: 1ste halvaar 1917, 496-499. The U-boat in question was UC-72, under the command of Oberleutnant zur See, Ernst Voigt.
} 
Fredrik's ship, DS Nydal, had been delivered to the company DS AS Vestlandet, managed by Frimann \& Pedersen, in January 1917. The ship had a crew of 23 and was on her way from New York to Bordeaux with general cargo. DS Nydal had the Norwegian red, white and blue painted on the side of the hull, in order to signal neutrality. However, this was of little use after the Germans introduced unrestricted submarine warfare on 1 February 1917.

Four Norwegian ships_-DS Nydal and another steamship, as well as two sailing vessels — were sunk by German forces on this Saturday in May 1917. All the seafarers - 42 persons from the two steamships and 47 from the two sailing vessels - survived, but only after enduring arduous voyages in the lifeboats. Some of the crew from the frigate Asra were the most unfortunate. After two tough days in the lifeboats, they were taken on board the Danish ship Hans Broge. However, less than 12 hours after they had been saved, and before they had managed to reach land, the Danish ship was attacked. The sailors had to leave a sinking ship again. ${ }^{2}$

Being sunk twice in the span of 72 hours was not common, but the First World War undoubtedly took its toll on seafarers, ships and shipping companies. Norwegian neutrality had been challenged even before the Germans started their unrestricted submarine warfare. Interruption of Allied supply lines, by means of mines, raiders and the dreaded $U$-Boote, was a key element of the German strategy.

As the war progressed, the threats changed. In 1914, during the first months of the war, the majority of the lost vessels were victims of mines. The North Sea had quickly been turned into a veritable minefield, with only narrow corridors from the UK to The Netherlands and Scandinavia open to traffic. ${ }^{3}$ In 1915 more than two-thirds of the lost Norwegian ships were sunk by torpedoes or grenades. The German cruisers were the main danger, but their efficiency was drastically curtailed by difficulties in obtaining sufficient coal. In the final years of the war, the dreaded submarines_-invisible and deadly_- took over. ${ }^{4}$

\footnotetext{
${ }^{2}$ Brochmann (1928, 114-115) and the report from the maritime inquiry in Sjøforklaringer over norke skibes krigsforlis, 1914-1918. B. 2: 1ste halvaar 1917, 501-502.

${ }^{3}$ For a captain's account of the difficulties of navigation in such waters-and in wartime in general - see Øvreseth (1932), which also includes maps detailing the extent of the mine operation.

${ }^{4}$ Petersen (1949, 203-204).
} 
By the end of the 1914-18 war, around half the Norwegian fleet had been sunk or had disappeared, and more than 2100 seafarers had lost their lives. These substantial losses occurred despite the fact that the Norwegian government on 4 August 1914 declared neutrality. The country had less than ten years' experience of managing their own foreign affairs, and had no interest in the blocs, rivalries and political power play that had become an increasingly important part of foreign affairs on the Continent. Norway had perfected a policy of sitting still and hoping not to be noticed. When the main European powers started fighting, this stance was futile.

However, even before the outbreak of the war, the isolationist policy had peculiar effects. In Berlin in April 1908, six countries signed the North Sea Declaration, which confirmed territorial divisions and sovereign rights in the North Sea. Norway, with the longest coastline to the sea, was not among the signatories. Instead, the country relied on its integrity treaty from November 1907, where the main powers had assured Norwegian independence, territorial integrity and "the benefits of the peace." 5 The Norwegian desire to have its neutrality formally secured by the agreement, had been lost in negotiation. This "preserved Britain's freedom of manoeuvre in and around Norway in time of war."

The fact that Norwegian neutrality was neither recognized nor guaranteed did not matter much. Shortly after the outbreak of the war, it became evident that the meaning of neutrality had become very flexible in the European political context. Germany invaded two neutral countriesBelgium and Luxembourg. ${ }^{7}$ Subsequently, the Germans initiated all-out attacks on neutral ships. However, they were not the only ones redefining and challenging the concept of neutrality. The Allied powers, with the UK in the lead, "requested the right to regulate the trade of neutral countries to a degree that was unique in the history of the world."

\footnotetext{
${ }^{5}$ Berg (1995, 71-98). The four major powers signing the integrity treaty were France, Germany, Great Britain and Russia. For the text of the North Sea Declaration, see Scott $(1908,200)$.

${ }^{6}$ Salmon $(1993,32)$.

${ }^{7}$ In fact, Belgium — sharing the Norwegian naivety and referring to its policy of perpetual neutrality - was the only other North Sea country that had not signed the 1908 agreement.

${ }^{8}$ Vogt $(1938,57)$.
} 
Norway, on her side, stretched the limits of what neutral countries could and should do. The country started out with a modest pro-British bias, and gradually moved closer and closer to the Allies. This lopsidedness can be explained by ideological, economic and security considerations. In 1917 Gunnar Knudsen, Prime Minister and shipowner, ensured the Americans that "Under no circumstances would we go with Germany." "However, there had been no animosity between Norway and Germany before the war. In fact, the links between the two countries had been strong, both at the commercial and at the personal level. Germany was Norway's most important trading partner before the war broke out. ${ }^{10}$ Moreover, Kaiser Wilhelm II had a particularly close relationship to the Norwegian coast and the Norwegian people, to the extent that the Norwegian fords had been his preferred summer vacation destination for more than 20 years. ${ }^{11}$

Slightly more than a week before the invasion of Belgium and Luxembourg, Kaiser Wilhelm II returned prematurely from Balholm in the Sognefjord, north-east of Bergen, in his yacht Hohenzollern. According to his memoirs, he had learnt from Norwegian newspapers about the worsening relationship between Austria and Serbia, but the very same newspapers report that he received a dépêche when he was taking his afternoon walk on Saturday 25th July 1914. After reading the telegram, he abruptly returned to the ship, and left Balholm without warning at half past six in the evening. ${ }^{12}$ At the same time, 38 German naval vessels

\footnotetext{
${ }^{9}$ Berg $(1995,255)$.

${ }^{10}$ With regard to Norwegian goods exports, Germany was the second most important countrythe 1913 share of 21 per cent was only toppled by the 24 per cent going to Great Britain and Ireland. However, almost 30 per cent of Norwegian imports came from Germany-while the British share was 25 per cent; Statistics Norway $(1914,55)$. Still, these figures disregard the trade in services - including shipping - where Great Britain played the key role. The commodity trade with Germany exceeded the British trade by 6 percentage points. If we include the gross freight earnings from shipping services, Norway's trade with Great Britain exceeded the trade with Germany by approximately 7.5 percentage points.

${ }^{11}$ It has been claimed that Wilhelm II had a particular interest not only in Norway, but also in Norwegians. Based on the belief that their grandfather was the illegitimate son of Der Kaiser, a family on the west coast in 2012 changed their name to Hohenzollern; Aftenposten, 15 February 2014, 34-37.

${ }^{12}$ Bergens Tidende, 260714, 1 . This story clashes with the Kaiser's memoirs, where he emphasizes that his returned started when he learned "from Norwegian newspapers—not Berlin—about the [...] Serbian note to Austria"; http://www.firstworldwar.com/source/julycrisis.htm
} 
that were in Norwegian waters were told to mobilize and return to their homeland.

When Hohenzollern travelled from the Norwegian coast to Wilhelmshafen in Germany, these waters were relatively safe. Just a few weeks later, the North Sea had become a strategically important part of the playing field and a crucial stage for the war theatre. Given the vital role that supplies and resources play during wars, the British attempt at isolating the German fleet and cutting off German supply became a lynchpin of their war campaign.

\section{The Crucial Role of Shipping During Wars}

As the US maritime historian Michael Miller has pointed out, the 1914-18 war at sea was not primarily about naval ships fighting for local and global hegemony and control. Rather, "the real sea battle in the First World War pitched German surface raiders, mines, and especially submarines against merchant shipping in an effort to interdict and destroy Allied overseas supply lines." 13 This was not soldiers against soldiers on land or marines against marines at sea-this was military might against civilian seafarers.

The outbreak of wars usually leads to an increase in the need for seaborne transport. The belligerents need to move troops and supplies. Moreover, with normal trade relations interrupted, even neutral countries are forced to rely on more distant sources of supply, and often ships have to resort to inconvenient lengthy detours. ${ }^{14}$ As a result, the demand for transport capacity increases. Parallel with this, the amount of tonnage available in the open market falls. Ships are requisitioned by the authorities and ship losses increase as a result of enemy action. Bottlenecks,

\footnotetext{
${ }^{13}$ Miller $(2017,1)$.

${ }^{14}$ For instance, rather than sourcing grain from Europe, Norway had to turn to the Americas. In 1913 Norway imported 50 tons of barley from the United States; by 1916 this had increased to almost 50,000 tons. Over the same period wheat imports from the United States increased from 2400 tons to 74,000 tons; Statistics Norway, Norges Handel 1913, 1914, 97-98 and Norges Handel 1916, 1918, 105. Imports of rye from Russia and Germany had amounted to more than 176,000 tons in 1913-by 1916 the imports were zero.
} 
restrictions and time-consuming inspections in ports reduce the efficiency of the available vessels, and material and labour shortages make it difficult to keep up newbuilding activity in the shipyards. Shipping is no different from other markets. Increased demand and reduced supply usually have one immediate effect: higher prices.

Norwegian shipowners had previously benefitted from the freight rate booms associated with conflicts in both near and distant waters. This time, the situation was even more favourable. The strong increase in international trade in the second half of the 19th century-often referred to as the first era of globalization-had already laid the foundation for the growth of the Norwegian merchant marine. However, the expanding trade also implied that Europe had become much more dependent upon foreign supplies to meet everyday needs. When the war broke out, Great Britain imported almost two thirds of the calories that were consumed, as well as much of the raw materials that kept the country's industry going; cotton, wool, petroleum, various ores and rubber. ${ }^{15}$ Shipping was more important than ever.

In the autumn of 1914, the German fleet was the second largest in the world, but British naval superiority rapidly neutralized the majority of the ships as the Allies took control of the sea lanes; "almost overnight, the German merchant flag disappeared from the high seas, not to reappear for more than four years." 16 Around 14 per cent of the world fleet, the share that the Central Powers held, was forced to remain in domestic and foreign ports. However, the blockade of Germany and Austria-Hungary also led to a decline in international trade, and a corresponding reduction in the demand for shipping. ${ }^{17}$

For the UK, superiority at sea was one of their main strengths - their policy had been "rule of thumb"-like: to have a navy that was at least as strong as the next two navies. The naval ships could be supplemented by vessels from the world's largest merchant marine. Relatively soon after the war had broken out, British merchant ships were put under Government control, and the authorities also introduced official maximum rates and

\footnotetext{
${ }^{15}$ Miller $(2017,1)$.

${ }^{16}$ Albion and Pope $(1968,233)$.

${ }^{17}$ Schreiner $(1963,89)$.
} 
standardized contract terms. By the end of 1915 , around 30 per cent of the British fleet had been requisitioned to contribute directly in the war campaign, transporting soldiers and other personnel, weapons and ammunition, provisions, etc.

Suddenly, two of Norway's most important competitors among the world's maritime nations were out of the picture. Some optimistic - and opportunistic - voices suggested that Norway had to take advantage of the situation. General Consul Storm, Chairman of Den oversjoiske eksportforening [The Overseas Exports Association] pointed out that Norway had an "opportunity to gain market shares in the world market that we will probably never see again" and should buy as many of the seized German ships as possible. ${ }^{18}$

This opportunistic business attitude was echoed in the press, where Norges Handels og Sjofartstidende, the leading newspaper for merchants and shipowners, presented the dilemma as a choice between the "poverty line" [fattigkasselinje] and the "line of action" [handlingens linje]. The latter alternative "would lead to wealth, just as surely as the former would lead to ruin." Neutral Norway "should take advantage of the situation $[\ldots]$ and increase our exports. Our ships shall continue to sail and earn the high freights that are offered. [...] Right now, when the competition is weaker, it is time to assert ourselves, both internally and externally." 19

The war years did see a spectacular increase in personal wealth in Norway, though the distribution was uneven. Speculators made rapid fortunes, and showed their windfall gains in obscene ways. For the majority of the population, however, the increased cost of living and the difficulties of obtaining crucial provisions were the main preoccupations. From 1914 to 1920 , prices multiplied by a factor of three, and rationing

\footnotetext{
${ }^{18}$ The article, originally in Norges Handels og Sjofartstidende, 090814, was reprinted in full in Bergens Tidende, 120814, 1 and by 21 August it had also reached the newspaper Nordkap. This offensive-in both meanings of the word — attitude was typical of the general consul. After the war, Storm offered his services to the Ministry of Foreign Affairs. When they declined his offer to act as "Envoyé Extraordinaire and Ministre Plénipotentiairie" in South America, his response was to publish an 80-page pamphlet about the politicians' "obstruction" and "tepidity"; Storm (1920). Based on the tone of this and other of his writings, it is evident that Storm today would have felt very at home in the comment section of online newspapers.
}

${ }^{19}$ Norges Handels og Sjøfartstidende, reprinted in Tromsø Stiftstidende, 190814, 1. 
and black market premiums aggravated the situation. In other words, Norway managed to follow both the "poverty line" and the "line of action". A similar balancing act was seen in international politics. Norway stayed neutral throughout the conflict, but was in reality strongly involved, and ultimately played an important role for the outcome of the war.

\section{Hands Across the North Sea}

Cut off from many of their normal sources by the British blockade, the German appetite for food and raw materials increased markedly. Norwegian exports to Germany more than doubled from 1914 to 1915 , and in 1916 export revenues amounted to almost 300 million kroner, more than four times as much as in $1913 .{ }^{20}$ Part of this was a result of increasing prices, but even when we correct for inflation, the Norwegian exports to Germany multiplied by a factor of more than three. Two types of commodities were particularly important during the first years of the war; minerals from Norwegian mines - in particular pyrite, copper ore and iron ore-and fish that could feed a German population on the brink of starvation. ${ }^{21}$

However, in 1916 Norway's westwards-leaning stance became more pronounced. This was not surprising - the British pressure for support intensified. Norway's position as a major cross-trader implied that politicians and shipowners had always tried to avoid challenging the UK, who through its navy and its network of bunkering stations was the ultimate maritime power. Britannia really ruled the waves, as guarantor of security, as energy provider and-most important for Norwegian shipowners — as market. The UK was still the centre of world trade, and an important entrepôt. Before the outbreak of the war, the number of Norwegian port

\footnotetext{
${ }^{20}$ Statistics Norway (1948, 223).

${ }^{21}$ Germany was the most important recipient of 24 of the 30 different types of fish and shellfish listed in Norwegian statistics in 1916; Denmark received more lobster, and the UK more salmon. With regard to canned fish, Germany was the leading importer in all categories, receiving marginally more than 50 per cent of all canned fish exports; Statistics Norway, Norges Handel 1916, 1918, 131-135.
} 
calls in the UK was more than four times higher than the corresponding number for Germany. ${ }^{22}$

This bias was not only linked to shipping, but more generally to the leading British position in the provision of coal and many other crucial products. As a result, several Norwegian branch organizations entered into agreements to ensure supply. In August 1915, The Association of Cotton Factories [Bomuldsvarefabrikkenes forening], fearing that cotton would be defined as "contraband", signed an agreement with the British Government. ${ }^{23}$ This is one example of how neutral Norway's allegiance would become more and more determined by the question of supplies; "our foreign policy [...] became a petty, mercenary, self-serving policy - a 'trade policy' in every aspect, practical and materialistic." ${ }^{24}$

A similar situation occurred in connection with fish exports. In 1915 , foreign buyers of fish were extremely active in Norway, and it has been suggested that the Germans tried to corner the market. ${ }^{25}$ The Norwegian fishing industry was in a difficult situation. Although Germany and the Continent were the main targets for their exports, they needed "coal, petroleum, salt, tin, olive oil, hemp and cotton for ships and fishing gear", and it was estimated that the British had a market share of around 85 per cent in the supply of these goods. ${ }^{26}$ For Norwegian fishermen, this was the worst catch of them all; Catch 22. They were in danger of losing the German market where they sold their fish, or in danger of losing the British inputs needed to satisfy this market.

An agreement on the sale of fish to Britain signed in the beginning of August 1916 was followed by an agreement on the export of copper ore

\footnotetext{
${ }^{22}$ More than 8000 Norwegian ships entered ports in Great Britain and Ireland in 1913, compared with less than 1800 ships entering German ports; Statistics Norway $(1916,48)$. The proportion of third-country trade was also higher for the British than for the German trade. Although Germany, as previously mentioned, actually supplied a higher share of Norwegian imports, the essential nature of the British products—in particular coal—gave them an advantage there as well.

${ }^{23}$ See Keilhau (1927, 97-104).

${ }^{24} \operatorname{Vogt}(1938,54)$.

${ }^{25}$ Hjort $(1927,18)$.

${ }^{26}$ Hjort $(1927,14)$; on the agreement between the UK and Norway regarding the sale of fish, see Hjort (1927, 9-193).
} 
and pyrite, signed at the end of the month. ${ }^{27}$ The fish agreement escalated tensions between Norway and Germany, and the latter responded by targeting shipping along the Norwegian coast. In the last week of September, ten Norwegian ships were sunk in the Arctic Ocean, and the ruthless manner in which the German submarines acted created a public outcry. ${ }^{28}$

With regard to the merchant marine, two considerations had to be taken into account. On the one hand, transporting cargoes for other countries had been its main employment, and was an important source of revenue. On the other hand, the ships played a crucial role in ensuring that Norway had fuel, food and other necessities. The transport to and from Norway thus became particularly important during the war, and the shipowners found that the authorities increasingly restricted their room to manoeuvre.

In December 1915 the government had introduced a provisional decree banning the sale of ships abroad, and this restriction was made into law in July $1916 .{ }^{29}$ However, the export ban was largely unnecessary. Norwegian shipping investors were in a buying — not in a selling — mood. In both 1915 and 1916 the imports of second-hand tonnage were three times higher than they had been in the years just before the war, and from the autumn of 1915 Norwegian owners "occupied practically all the capacity on shipyards in countries that were still neutral, primarily Norway, Denmark, the Netherlands and the United States." ${ }^{30}$ By the end of 1916, Norwegian newbuilding orders at US shipyards amounted to around 90 per cent of the country's annual production capacity. ${ }^{31}$

The Norwegian fleet reached a peak in August 1916, before the increased German aggression began to fully take its toll. More than 300,000 deadweight tons were lost in the last four months of 1916,

\footnotetext{
${ }^{27}$ As a result of the British dependence on imported foodstuffs, the entire exports of meat from Australia and New Zealand, and most of the Argentinian exports, had been bought up by the Board of Trade.

${ }^{28}$ As early as in November 1915 Sweden had denied submarines use of its territorial waters, except in a surface position in times of distress. A similar Norwegian resolution came 11 months later, and had only one exception from the total ban-submarines could enter Norwegian waters to save human lives.

${ }^{29}$ Keilhau $(1927,186)$.

${ }^{30}$ Haaland $(1940,18)$.

${ }^{31}$ Schreiner $(1963,363)$.
} 
compared with around 265,000 deadweight tons in the first two years of the war. ${ }^{32}$ The combination of a more violent German policy and a strong increase in the submarine fleet-which more than doubled during 1916 — can explain the higher losses.

The UK had by far the largest merchant marine at the start of the war, but had similar preoccupations as the Norwegians; at home, people and machines needed foreign inputs to be able to keep going. The authorities introduced a plethora of regulations, including compulsory voyage permissions, maximum freights and requisitioning, but even that was insufficient to cover their transport needs. They consequently cast their eyes on the neutral fleets, and had the means to persuade them: foreign steam shipping depended on British coal. By restricting access to this vital factor of production, British authorities could influence the manner in which the vessels were paid and used. In the first half of 1916 they introduced maximum freights for foreign ships on certain routes, and refused to deliver coal to neutral ships unless they had secured a return cargo that would bring them back to the UK. ${ }^{33}$

For a while, the cooperation with the British was organized along the "one in-one out" principle followed by nightclub bouncers on a busy Saturday night. Norwegian vessels that were ready to sail to Scandinavia or The Netherlands with coal cargoes were not allowed to leave until they were replaced by another Norwegian ship. ${ }^{34}$ These restrictions were relaxed when it turned out that the Norwegians reacted differently to owners from other neutral nations; "the dauntless Norwegians stuck to the dangerous work, but most others dared not risk their ships." ${ }^{35}$

A dispute about Norwegian exports of low quality pyrite to Germany led to a cessation of British coal exports to Norway from the end of 1916 . However, "it was evident that the dependence of Norway on British coal" and the Norwegian shipowners' large fleet made them "genuinely anxious to employ their vessels in the service of the Allies," with whom they were already "on friendly terms." ${ }^{36}$ In February 1917, shortly after the Germans

\footnotetext{
${ }^{32}$ Schreiner (1963, 134 and 304); refers to ships lost as a result of war hostilities.

${ }^{33}$ Hodne (1981, 448-449) and Klovland (2017, 10-12).

${ }^{34}$ Schreiner $(1963,165)$.

${ }^{35}$ Schreiner $(1963,166)$ and Albion and Pope $(1968,241)$.

${ }^{36}$ Fayle (1923b, 47).
} 
introduced unrestricted submarine warfare, the Norwegian authorities accepted the demands, and the British stopped twisting the Norwegian arms.

Around the same time, the British Minister of Blockade, Lord Robert Cecil, approached the Norwegian authorities with the view of purchasing tonnage. ${ }^{37}$ The basis for the approach was that "Norway had a greater amount of tramp tonnage to place on the freight markets than any other country except Great Britain herself." 38 The German escalation of the naval warfare-with a large number of much more efficient submarines-implied that the Norwegian fleet had become increasingly valuable. This paved the way for the tonnage agreement with the UK, negotiated in the spring and entering into force in the summer of 1917.

The tonnage agreement was a strange beast; it was negotiated by the Norwegian Shipowners' Association and the British legation in Oslo, but with both countries' authorities-the British Government and the Norwegian Provianteringsdirektoratet [Ministry of Provisioning]-looming insistently in the background. ${ }^{39}$ The idea was that "all Norwegian shipping not required for the trade of Norway herself should, so far as possible, be employed in Allied interests, in return for a guarantee of the Norwegian coal supply." ${ }^{40}$ As a result of this agreement, neutral Norway devoted its most important asset-the merchant marine-clearly to one side in the conflict. By this time, there was no doubt about where Norwegian allegiance lay.

According to the agreement, a substantial share of the Norwegian fleet was time chartered through Furness Withy \& Co., as agents for the British authorities. Moreover, in the dangerous North Sea trade, Norwegian ships—which due to neutrality could not be armed-were replaced by British vessels. ${ }^{41}$ Consequently, coal to Norway was "carried

\footnotetext{
${ }^{37}$ The fact that the British had their own Minister of Blockade illustrates the crucial role of this aspect of the war. Ironically, the Rt Hon Lord Robert Gascoyne-Cecil, First Viscount Cecil of Chelwood, CH, PC, QC, was in reality a keen supporter of free trade, and in 1937 won the Nobel Peace Prize for his work with the League of Nations.

${ }^{38}$ Fayle (1923a, 274).

${ }^{39}$ The nature of the agreement implies that there was no signed contract. Instead, the previous correspondence was used as the basis for the arrangement; Schreiner (1963, 176-177).

${ }^{40}$ Fayle $(1923$ b, 48).

${ }^{41}$ Norges Rederforbund $(1960,17)$.
} 
by armed British ships, among whom losses were likely to be smaller" while "the Norwegian steamers should be available for Allied service elsewhere." ${ }^{22}$ The red-white-and-blue on the ships' side, which had previously functioned well when neutrality was an advantage, had to be substituted by war paint and camouflage, because it would otherwise signal to the submarines that the ship was unarmed. ${ }^{43}$

In late 1917, around 900,000 dead weight tons of Norwegian shipping, in addition to the requisitioned ships, served the Allies on time charters to the Executive, or on a trip-by-trip basis in the coal and ore trades. However, the important thing was not only the number of ships, but also the willingness to engage them in the most dangerous waters. A survey from January 1918 shows that 547,000 gross tons of Norwegian ships were performing Allied service in the war zone, compared with a total of 141,000 tons of Dutch, Swedish and Danish ships. The difference is remarkable: although Norway only owned slightly more than a third of the "neutral" Dutch-Scandinavian fleet, they had almost 80 per cent of the crucial tonnage servicing the war zone. ${ }^{44}$

Norway's novel definition of neutrality was exemplary from a British point of view: "In striking contrast to the friction which had arisen with so many neutrals, British relations with Norway were on a friendly footing." ${ }^{35}$ When the United States entered the war in April 1917, the pressure on Norway intensified. The Americans demanded a complete termination of Norwegian exports to Germany, in order to secure food supply to Norway. While the Americans and the Norwegians played diplomatic ping pong, daily life became characterized by rationing, inflation and civil unrest. The famous explorer and scientist Fridtjof Nansen represented Norway in the discussions with the United States. ${ }^{46}$ Initially, he suggested limiting food exports from Norway to Germany to 40,000 tons of fish and fish products, but only when Norway introduced bans

\footnotetext{
${ }^{42}$ Fayle (1923b, 218).

${ }^{43}$ Kloster $(1935,76)$.

${ }^{44}$ Estimated on the basis of Fayle (1923b, 261); ships in national trade with the UK are excluded. ${ }^{45}$ Fayle (1923b, 47); see also Hurd (1924, Vol. II, 244).

${ }^{46}$ Among the tasks he faced, was securing supplies to Roald Amundsen's expedition through the North East Passage, which led to "large and totally unexpected difficulties"; letter dated 040118; https://urn.nb.no/URN:NBN:no-nb_digimanus_17502
} 
and restrictions on the exports of minerals and other military articles to the Central Powers was it possible to conclude a Norwegian-American agreement. The agreement, with severe limits on Norwegian exports to Germany, came into force in May 1918, after nine months of negotiations. Norway had truly become "the neutral ally." ${ }^{7}$

One of the main reasons for Norway's westward stance was the deteriorating view of Germany in public opinion, which made it easier for the authorities to align their policies with the Allies. The manner in which submarine warfare destroyed human lives and merchant ships-neutral lives and neutral ships_changed public opinion and inflamed antiGerman sentiments. For the majority of Norwegian citizens, Germany and the Central Powers became "the enemy" during the course of the war.

Domestic incidents contributed to the changing attitude. In Bergen, Den store spionsaken [The great espionage affair] caused public outrage in the spring of 1917 . Members of a spy ring had sold information about Norwegian ship departures to the Germans, betraying their compatriots. ${ }^{48}$ The court case led to riots and demonstrations outside the courthouse, where the accused were harassed by a large mob. ${ }^{49}$ In Kristiania, in an unprecedented break of diplomatic courtesy, the German diplomat and spy "Baron von Rautenfels"-actually the Finnish-born civil servant Walter Harald von Gerich—was arrested in June 1917. He had more than 200 bombs in his possession, some hidden in trunks that had been sealed by Auswärtiges Amt, Berlin [The Foreign Office, Berlin]. Among the explosives, which totalled almost a ton, were nine bombs concealed as lumps of coal, to be hidden in the bunkers depots of ships. Norwegian newspapers linked the case to previous "suspicious accidents at sea." 50

\footnotetext{
${ }^{47}$ Berg $(1995,228-244)$; in the end, the fish exports were capped at 48,000 tons. The term "the neutral ally" is linked to Riste (1965).

${ }^{48}$ Four of the 14 spies that were arrested worked for Det Bergenske Dampskipsselskap, Bergen's leading shipping company. Due to the company's relatively limited losses at sea, the British authorities insinuated that "the owners may not have been completely ignorant of the malpractices"; see Keilhau (1951, 331-334).

${ }^{49}$ Bergens Tidende, 301117, 5 and 7-9. In addition to animosity against the accused, the basis for the "riots" was the relatively low number of police officers controlling the long queue of curious onlookers.
}

${ }^{50}$ Dagbladet, 230617, 1; Søhr (1938, 76) and Hambro (1958, 168-185). 
The accomplices of "the bomber baron" were given relatively long jail sentences in Norway. "Baron von Rautenfels" himself was expelled from the country, but was given an amnesty in Germany and escaped prosecution. ${ }^{51}$ This is characteristic of the international political situation during the war: the Norwegians pretended that they were neutral, and the Germans pretended that they respected the neutrality. ${ }^{52}$ During the First World War, political, economic, strategic and military considerations overlapped and clashed, creating uncertainty and complexity for individuals and for businesses.

\section{War Risk and War Losses}

Wars greatly increase the risk associated with shipping, and risk is sometimes difficult to deal with from a commercial perspective. Some weeks after the start of the war, Norwegian shipping companies, in cooperation with the government, established a compulsory and mutual war insurance arrangement. ${ }^{53}$ This was an important step-crippling insurance premiums and lack of access to war insurance immobilized the fleet. Norwegian ships were already in or on their way to the lay-up buoys. Insurance premiums of 25-30 per cent of the value of the vessel had been quoted for some voyages across the North Sea, and the reduced shipping activity threatened both Norwegian imports of necessities and the freight revenues that financed them. ${ }^{54}$

In the UK, Denmark and Sweden the authorities had established insurance arrangements, but the value of the Norwegian merchant marine, relatively to the size of the public coffers, made such a solution difficult in Norway. Moreover, it was claimed that "Norwegian shipowners were known for chartering their ships on risky voyages, almost like a predilection, if the profits encouraged it" - not a strategy that will

\footnotetext{
${ }^{51}$ Søhr (1938, 72-98).

${ }^{52}$ The German Embassy had been invited to the opening of the sealed trunks, but did not turn up. When it was proven that they had broken the diplomatic rulebook, an obscure military agency was blamed.

${ }^{53}$ Nilsen \& Thowsen $(1990,10)$.

${ }^{54}$ Petersen $(1949,177)$.
} 
convince insurers. ${ }^{55}$ Regardless of whether or not this claim was correct, if this was the general opinion, it would negatively affect shipowners' ability to obtain affordable insurance terms.

A committee was established on 11 August 1914, headed by Joh. Ludwig Mowinckel, Bergen shipowner and President of the Odelsting, one of the Parliamentary chambers. The committee worked rapidly, and the day after it had been appointed suggested the establishment of a compulsory and mutual insurance arrangement, where the authorities granted a temporary guarantee. Consequently, the costs of every individual loss would be shared by everyone. This solution was supported by both the politicians, who wanted to limit their own risk, and the shipowners, who wanted to limit the authorities' influence.

The increasing insurance costs were warranted. Neutral Norway suffered heavily during the First World War. More than 2100 seafarers lost their lives. Almost 950 ships, with a tonnage of more than 1.3 million gross register tons (grt)_corresponding to around half the 1914 fleetwere lost. ${ }^{56}$ Given that they were sailing for a neutral nation, the Norwegian ships were unable to retaliate when they were attacked.

Figure 3.1 shows the official Norwegian loss figures during the war. With the introduction of unrestricted submarine warfare in February 1917, and subsequently with the US entry into the war, developments changed dramatically. The new German policy-targeting all ships around the British Isles, outside France and Italy and in the Eastern Mediterranean-implied that the target became the ships, not their cargoes. The introduction of convoys in the North Atlantic in the spring of 1917 managed to drastically reduce the losses in that region, and the decline was strengthened by the deployment of Norwegian ships to lessdangerous waters after the tonnage agreement.

\footnotetext{
${ }^{55}$ Keilhau $(1927,32)$.

${ }^{56}$ See Fig. 3.1, which is based on Statistics Norway (2000), Table 115, 115 and Statistics Norway (1948), Table 131a, 248. In addition to the data presented there, 943 seafarers and 69 ships with an aggregate tonnage of slightly more than 60,000 gross tons disappeared during the war, most likely as a result of mines or torpedoes; Statistics Norway $(1919,63)$. While these vessels are mentioned in the footnotes of subsequent statistics, the seafarers have disappeared there as well. Moreover, one sailing ship and three other ships sunk by mines in 1919, which left 24 sailors dead, are not included in the data. Figures for 1914 refer to the period after 1 August, while 1918 refers to the full year.
} 


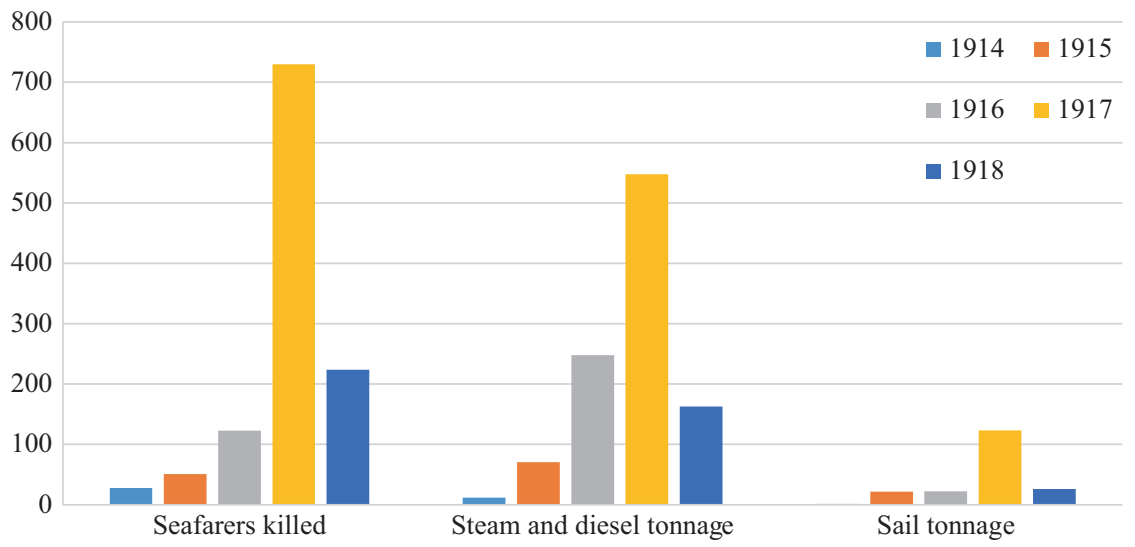

Fig. 3.1 Norwegian losses during the First World War by year, 1914-1918, seafarers and 1000 grt. (Sources: Statistics Norway (1948, 2000). See footnote)

The acceleration of the German war at sea is evident from the statistics-as is the efficiency of the convoys at the later stages of the war. Regardless of the high losses, "posts at ships that were sailing in the danger zone were always in high demand," according to the economist Wilhelm Keilhau. With a lack of reality orientation that can often be found behind a large oak desk, he claimed that "For many [seamen] the spirit of adventure must have played an important role." 57

The loss of a ship was not necessarily bad for the company's business. In the summer of 1917 it was claimed that a share in DS AS Vestlandet, the company that owned the recently torpedoed Nydal, was "a good paper," partly as a result of the income associated with the sinking. ${ }^{58}$ The ship's insurance had amounted to more than NOK2.1 million, and the company had a book profit of NOK1.4 million as a result of the

\footnotetext{
${ }^{57}$ Keilhau (1927, 319-320). Wilhelm Christian Keilhau was Professor of Economics at the University of Oslo. He gradually reoriented his writings towards economic and business history, and his prolific authorship includes several books that were written because he had an axe to grind. Keilhau's uncle had been Minister of Defense in Norway in 1914, but was replaced two days after the country had declared its neutrality.

${ }^{58}$ Bergens Tidende, 260917, 7. A misprinted telegram about a torpedoed ship plays a central role in the Norwegian rags-to-riches "yuppie comedy classic" Bør Børson jr.; Falkberget (1920, 182-188).
} 
insurance payout after the Germans had sunk the ship. ${ }^{59}$ While such profits were subject to income tax and war gains tax in the first years of the war, from July 1917 insurance profits became tax exempt if they were reinvested in new shipping capacity.

For the seafarers on board the ships, the case was of course different. They received a hazard bonus as a result of the war, and half a month's extra pay if the ship was captured or sunk by the Germans. ${ }^{60}$ This sounds ruthless, but was in fact not too bad: Danish and British seafarers actually had their wages stopped from the moment the ship was sunk. There was also compensation for personal belongings, and here we see the class system at play: captains were given 1000 kroner, mates were given 600 kroner and compensation for the rest of the crew was 400 kroner to cover clothes and other personal items that were lost. ${ }^{61}$

\section{Jobbetid: The Financial Boom}

While the seafarers were counting their blessings, speculators were counting their money. The war led to an enormous increase in freight rates, and in revenues. In 1916, gross freight earnings_- what foreigners paid for Norwegian transport services-were more than four times higher than they had been five years earlier, even when we take inflation into account. This massive inflow of money fostered optimism-shipowners reinvested their earnings, and shipping investments became attractive even to those outside the sector.

The war led to an enormous "investment" activity, where some shipping company shares doubled in value, then doubled again, and where the volume of transactions bordered on the ludicrous. High risk led to high potential profits: "Yesterday I bought a Tønsberg-boat at eleven in the morning for three and a half million, and sold it again at one o'clock for four," boasts one of the shipowners in Nordahl Grieg's classic play Var

\footnotetext{
${ }^{59}$ Bergens Tidende, 180418, 5.

${ }^{60}$ Pedersen $(1952,170)$. In April 1918 this was increased to three months. Some shipowners were more generous than others; Fred. Olsen offered torpedoed sailors wages for the rest of the year, even if their ship had been sunk in January.

${ }^{61}$ Tønnessen (1960, 116).
} 
are og vair makt. ${ }^{62}$ The freight rate boom led to "an almost insatiable appetite for shipping shares and ship parts." ${ }^{63}$

Still, economic success was primarily a question of good or fortunate timing. "The shipowners that had bought ships in the first half of 1914 [...] were winners in life's peculiar lottery" and for the first years of the war values increased steadily. ${ }^{64}$ During 1915 the price of a relatively large ship multiplied by a factor of five, and the second-hand price exceeded the newbuilding price for a similar vessel by 80 per cent due to its prompt availability. ${ }^{65}$ The price of the shares of shipping companies that owned such tonnage naturally soared.

From the end of 1914 to the peak in 1918 the value of shipping shares multiplied by a factor of almost six. Because freight rates showed particularly pronounced boom movements, shipping shares became the favoured speculative object among those looking for a quick boost of their personal wealth. There was a real economic fundament for the boom in the beginning; the high freight rates led to record profits-even after the increases in coal prices, wages and insurance costs were taken into account. However, as the war progressed, the development acquired all the properties of a "bubble." Investors ventured their money based on the expectation of continuing share price increases, rather than on the basis of future revenues.

The important factor was not the company's revenue stream, but the ability to sell the shares at a higher price at a later stage. The aim was to find an even greater fool in a game of musical chairs. Norway "had never seen a gold fever like that, and probably not a similarly vulgar and provocative exhibition of money." 66 Figure 3.2 illustrates how the shipping industry, more than other sectors, was affected by the boom and bust during the war. ${ }^{67}$

\footnotetext{
${ }^{62}$ Grieg $(1935,84)$.

${ }^{63}$ Thowsen $(1983,199)$.

${ }^{64}$ Keilhau $(1927,10)$.

${ }^{65}$ Kloster $(1935,40)$. In one case, the sale price of a ship increased by more than 300 per cent from May to December; Kloster $(1935,41)$.

${ }^{66}$ Egeland $(1963,9)$.

${ }^{67}$ Figure 3.2: Based on Keilhau (1927, 344-346). Data refer to end of month. The total index consists of the following indices (weighting in parentheses): Manufacturing (1/3); Shipping (1/3); Banking (1/6); Insurance (1/15); Whaling (1/15); Transport, etc. (1/30).
} 


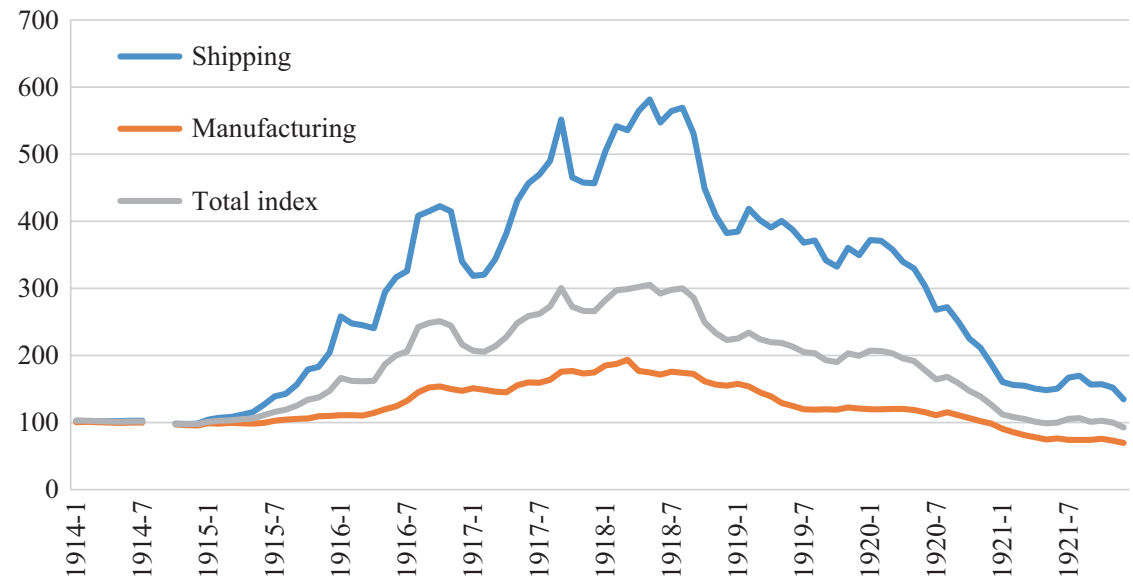

Fig. 3.2 The shipping speculation boom, stock exchange indices $(1913=100)$, 1914-1921

From a societal point of view, the development was unfortunate. The war, inflation and rationing accentuated the difference between the haves and the have-nots. Shipping investors undoubtedly belonged to the first group. In 1917 inequality in Norway was at its highest point in modern history. ${ }^{68}$ Quite a lot of people became wealthy from speculation, but most major maritime cities typically had one or two entrepreneurs that stood out. This development was most pronounced in Kristiania and Bergen, where we find the most liquid stock exchanges.

In 1915 the shipbroker Christoffer Hannevig jr. in Kristiania invited investors to buy four old sailing ships that would be fitted with engines, and promised that one voyage would give a return of "more than 50 per cent of the purchase price." ${ }^{69}$ At this point Hannevig was an outsiderand even frowned upon by established shipowners-but he still became the archetypal example of the new-found wealth during this early yuppie period. ${ }^{70}$ By 1917 his fortune was allegedly NOK150 million-around

\footnotetext{
${ }^{68}$ Aaberge et al. $(2016,22)$.

${ }^{69}$ See the advertisement in Morgenbladet, 140215, 11.

${ }^{70}$ The Norwegian term for the period is jobbetid, referring to the jobbing of stocks-short-term investments looking for rapid profits, often associated with the British South Sea Bubble in the 18 th century.
} 
NOK5 billion in today's money: "Every child in Norway knows Hannevig. He has already become a mythical character, a Norwegian version of King Midas or brewer Jacobsen, a young Alladin or a new, shining Askeladd. Even before he started to splash millions about, it was established that he was the incarnation of the wonderful fairy-tale called Norwegian shipping during the World War."71

Hannevig owned shipyards in the United States and a bank with offices in Old Broad Street in London, in New York and in Aasgaardstrand-a Norwegian village of around 300 souls: "incredible fortunes have been made in a couple of years; shipowners have had to establish their own banks in order to accommodate the money."72 In 1921 Hannevig, who by then was in his late thirties, and several of his companies went bankrupt. He subsequently spent a lot of energy on litigation against the US authorities, claiming compensation for yards that had been confiscated when the United States entered the war. The First World War's Norwegian King Midas died broke in New York in 1950.73

Tryggve Sagen, one of Hannevig's partners, is another rags-to-richesto-rags story in Kristiania, while in Bergen the boom was associated with Erik Grant Lea. ${ }^{74} \mathrm{He}$ was a serial entrepreneur, who was also the victim of comparisons with King Midas and Aladdin. ${ }^{75}$ Like many "jobbers," Lea had managed to get a large share of outside capital in his companies; in the first one he owned only 16 of the 750 shares. ${ }^{76}$ This made him vulnerable for shareholder revolts, and in 1917 six of his companies were taken over by another "typical speculative partnership" — a dog-eat-dog world. The new managers were Bjørnstad and Brækhus, who also took

\footnotetext{
${ }^{71}$ Dagbladet, 281017, 6. King Midas should be well-known, and "Alladin" is a mis-spelt "Aladdin." "Brewer Jacobsen" refers to Carl Jacobsen, founder of the Danish brewery Carlsberg and regarded as one of the most successful businessmen in Scandinavia. Askeladden is one of the main characters in Norwegian folk tales, typically succeeding where others fail.

${ }^{72}$ Dagbladet, 030319, 4.

${ }^{73}$ Hannevig died, but the court cases lived on. In March 1960, the Norwegian Parliament discussed the aftermath of the case for the ninth time, as a response to a decision in the US Court of Claims the previous year; Norway, Parliament, Stortingsmelding 60 (1959-1960).

${ }^{74}$ On Sagen, see Haugstad (2017).

${ }^{75}$ See Tveit (1972) for a biography of Lea and reference to the comparison, and Imset (2009) on Hannevig.

${ }^{76}$ Thowsen $(1983,204)$.
} 
over DS AS Vestlandet, to benefit from the insurance payout after $N y d a l$ had been torpedoed..$^{77}$ In the period 1917-1920 Bjørnstad and Brækhus "raided" 15 different companies to gain control of valuable tonnage.

Ships and ship shares changed hands at high frequency-and usually at higher and higher prices. Before the war there had been eight stockbrokers in Kristiania-during the war the number grew to several hundred, and informal transactions took place in restaurants and cafes. The boom and bust in the equity market cast long shadows. Several decades after the war, the image of the stock exchange was negative to many people, linked with speculation, unrestrained risk-taking, uninhibited spending and a gambling mentality that was alien to Norwegian values. Moreover, shipping was seen as the archetypal gambling activity; "old, peaceful Kristiania [had] succumbed to a deluge of papers, of shares, of warrants and of contract notes."78

The speculative fever was fuelled by an abundance of money so large that even crooks from abroad were attracted to it. The Australian Mister Angus, who promoted the idea of a self-stopping locomotive, left the country after having deprived investors of their funds. "There were invitations to subscribe [to new shares] that even the most ignorant must have understood were meaningless." ${ }^{\prime 79}$ In the absence of good investment objects, the wealthy - and in particular the newly wealthy-chose risky investments and conspicuous consumption.

The abundance of money among the successful speculators was partly channelled into new investments, fanning the flames of the boom. Still, there were also funds for other purposes. The phenomenal profits were channelled into luxurious houses, expensive food and wine, horses and yachts. Enormous houses of exquisite materials were built, and the newspapers carried a large amount of advertisements for castles in Sweden and estates in Denmark. Christoffer Hannevig bought a 154-foot-long racing sailboat that had previously belonged to Count Gustav Krupp, but had been taken as prize of war in Germany in 1914. Sailboats were status symbols, and one investor owned a 12-metre, a 10-metre and an 8-metre,

\footnotetext{
${ }^{77}$ Thowsen $(1983,313)$.

${ }^{78}$ Keilhau $(1923,44)$. The book was published anonymously, with no reference to the author.

${ }^{79}$ Vogt $(1938,143)$.
} 
in addition to a large motorboat and an inland estate equipped with telephones made of silver. ${ }^{80}$

Another favoured investment object was fine art. For investors like Hannevig and Lea, the boom and the wealth were temporary. However, for Norway, the abundance of funds had long-term cultural effects. ${ }^{81}$ In 1917 large sums were donated to establish a trustee association for the Norwegian National Gallery. Tryggve Sagen, who was among the founders, had the previous year donated 60,000 kroner to the gallery earmarked for the purchase of foreign art- 50 per cent more than the gallery's annual budget and almost four times as much as the gallery's public funding for art purchases. Works of art by famous and soon-to-be-famous artists were bought inexpensively on the Continent, helped by a strong Norwegian krone and the desperate circumstances in war-torn Europe; "the international art market had a broken back, and a group of trustees in Kristiania had a honeypot bursting with money." 82

Fine art was hardly a concern for the population in general. For most Norwegians, the abundance of money was seen mainly in rising prices, and their bitter experience was that wages did not keep up. In 1916 and 1917 demonstrations and strikes were frequent in Kristiania and the other major cities. "Sailors are drowning, people are starving, capital is reaping the benefits," was the disillusioned message on a poster in a rally against the high cost of living.

As a result of the increasing inequality, social tensions grew-particularly in the cities and other places with manufacturing industry, where food was bought, rather than grown. Ordinary workers - and even more so the unemployed - struggled with rationing and the rapid increase in the cost of living. The lavishness and luxury that characterized the lifestyle of the most successful speculators were provocative. The result was a feeling of contempt and a growing class consciousness-syndicalists, communists and anarchists gained support. The revolution in Russia had created hope. Norwegian politics became polarized and was permanently changed.

\footnotetext{
${ }^{80} \operatorname{Vogt}(1938,158)$.

${ }^{81}$ In recent years, two fascinating books that deal with the link between the war profits and the arts have been published; Haugstad $(2015,2017)$. The latter book is a biography of Tryggve Sagen.

${ }^{82}$ Haugstad (2015).
} 
The authorities increased their influence on the Norwegian economy during the war. Rationing and maximum prices became the order of the day. Monopolies were established and public expenses increased rapidly. The tax burden increased. Johan Schreiner, who has written the most extensive work on Norwegian shipping during the war, emphasizes that "the relationship to the authorities was radically changed [as] the traditional freedom of action was drastically restrained by commands from domestic and foreign branches of government. [...] A similar transformation occurred in the relationship between shipping company and seafarers." 83

The Norwegian authorities and shipowners managed the difficult balancing act that the First World War represented relatively well. At the same time, it is evident that in public opinion, shipowners lost some of their sheen-they were now more closely associated with speculators than with society builders. There were still shipowners who played an important political role-Joh. Ludwig Mowinckel, for instance, would go on to become Prime Minister on three occasions in the interwar period. However, the boom had been particularly pronounced in shipping, and although fly-by-night "newcomers"-who saw casino-like opportunities in shipping-had been responsible for the worst excesses, many longterm, responsible shipowners were also tainted in the public's perception.

The 1920s would bring economic challenges as well. In the words of one shipowner, "The transition from the golden boom years was difficult, prices fell vertically, and many of those who at the beginning of 1920 were millionaires - at least on paper and according to tax reports and share values - were suddenly stony broke. Every day new bankruptcies and new misery, frauds and hair-raising stupidity were revealed." ${ }^{4}$

When peace returned in November 1918, many things had changed, both in Norway and at the international stage. As shipowners prepared for the post-war boom, the "first era of globalization" was still an ideal. Unfortunately, the 1920s and the 1930s never lived up to the expectations.

\footnotetext{
${ }^{83}$ Schreiner (1963, ii). In 1915 it was decided that the Norwegian Shipowners' Association would function as an employers' organization for the seafarers, and while this was initially of limited importance, it became an important role when peace returned.

${ }^{84}$ Ditlev-Simonsen (1945, 157-158).
} 


\section{Bibliography}

R.G. Albion \& J.B. Pope (1968) Sea Lanes in Wartime - The American Experience, 1775-1945, second enlarged edition (Hamden: Archon Books)

R. Berg (1995) 'Norge på egen hånd 1905-1920', Norsk utenrikspolitikks historie, Vol. 2 (Oslo: Universitetsforlaget)

D. Brochmann (1928) Med norsk skib i verdenskrigen (Oslo: Norges Handels \& Sjøfartstidende)

O. Ditlev-Simonsen (1945) En sjøgutt ser tilbake (Oslo: Cappelen)

K. Egeland (1963) Var are og vair makt (introduction) (Oslo: Gyldendal Norsk Forlag AS)

J. Falkberget (1920) Bør Børson jr. (Kristiania: H. Aschehoug \& Co.)

C.E. Fayle (1923a) 'Seaborne Trade', Vol. II, Offcial History of the Great War (London: John Murray)

C.E. Fayle (1923b) 'Seaborne Trade', Vol. III, Official History of the Great War (London: John Murray)

N. Grieg (1935) Vàr are og vår makt (Kristiania: Gyldendalske Bokhandel)

C.J. Hambro (1958) Under den forste verdenskrig (Oslo: Gyldendal)

B. Haugstad (2015) Krig, kunst og kollaps - Reder-kapitalen og Nasjonalgalleriet (Oslo: Schreibtisch Forlag)

B. Haugstad (2017) Tryggve Sagen - Gutten Norge glemte (Oslo: Schreibtisch Forlag)

J. Hjort (1927) Utenrikspolitiske opplevelser under verdenskrigen (Oslo: Gyldendal Norsk Forlag)

F. Hodne (1981) Norges økonomisk historie 1815-1970 (Oslo: J.W. Cappelens Forlag)

A. Hurd (1924) 'The Merchant Navy', Vol. II, History of The Great War (New York: Longmans, Green \& Co.)

C. Haaland (1940) Norges skipsfart - hva den var og hva den er (Oslo: Blix Forlag AS)

F.W. Ilboe (1970) Fare Fare Sjømann (Oslo: H. Aschehoug \& Co.)

G. Imset (2009) Christoffer Hannevig: gull, krig og krakk (Oslo: Pax)

W. Keilhau (1923) Tore Tank (Oslo: H. Aschehoug \& Co.) The book was published without the author being identified.

W. Keilhau (1927) Norge og verdenskrigen (Oslo: H. Aschehoug \& Co.)

W. Keilhau (1951) Norges eldste linjerederi (Bergen: BDS)

K.U. Kloster (1935) Krigsår og gullflom - Skibsfarten under verdenskrigen (Oslo: Gyldendal) 
J.T. Klovland (2017) 'Navigating through torpedo attacks and enemy raiders: Merchant shipping and freight rates during World War I', Discussion paper SAM 07/2017 (Bergen: NHH - Norwegian School of Economics)

Miller, M. (2017) 'Sea Transport and Supply', in U. Daniel, P. Gatrell, O. Janz, H. Jones, J. Keene, A. Kramer \& B. Nasson, 1914-1918-online. International Encyclopedia of the First World War, issued by Freie Universität Berlin, Berlin 2014-10-08

Nilsen, Tore L. \& Atle Thowsen (1990) Handelsflàten i krig 1939-45 (Bergen: Bergens Sjøfartsmuseum)

Norges Rederforbund (1960) Norsk skipsfart $i$ vårt århundre: Hovedlinjer $i$ utviklingen (Oslo: Norges Rederforbund)

K. Petersen (1949) Norsk dampskipsfart blir en stormakt på verdenshavene (Trondheim: E. Bruns Bokhandels Forlag)

O. Riste (1965) The Neutral Ally: Norway's Relations with Belligerent Powers in the First World War (Oslo: Universitetsforlaget)

P. Salmon (1993) "'Between the Sea Power and the Land Power": Scandinavia and the Coming of the First World War', Transactions of the Royal Historical Society, 3, 23-49

J. Schreiner (1963) Norsk skipsfart under krig og høykonjunktur, 1914-1920 (Oslo: Norges Rederforbund/Cappelen)

J.B. Scott, (1908) 'The North Sea and Baltic Agreements', The Advocate of Peace, 70:8, 200

Statistics Norway (1914) Norges Handel 1913 (Kristiania: Det Statistiske Centralbyraa/H. Aschehoug \& Co.)

Statistics Norway (1916) Norges Skibsfart 1913 (Kristiania: Det Statistiske Centralbyraa/H. Aschehoug \& Co.)

Statistics Norway (1918) Norges Handel 1916 (Kristiania: Det Statistiske Centralbyraa/H. Aschehoug \& Co.)

Statistics Norway (1919) Statistisk aarbok for kongeriket Norge 1919 (Kristiania: Det Statistiske Centralbyrå/H. Aschehoug \& Co.)

Statistics Norway (1948) Statistiske oversikter 1948 (Oslo: Statistiske Sentralbyrå)

Statistics Norway (2000) Statistisk Årbok 2000 (Oslo: Statistics Norway)

J. Søhr (1938) Spioner og bomber: fra opdagelsespolitiets arbeide under verdenskrigen (Oslo: Tanum)

O.J. Storm, (1920) Utenriksreformen og Funktionarstyret i Utenriksdepartementet (Kristiania: AS Sverre Mortensen, Ltd.)

A. Thowsen (1983) 'Vekst og strukturendringer i krisetider 1914-1939', Bergen og Sjøfarten IV (Bergen: Bergens Rederiforening og Bergens Sjøfartsmuseum) 
N. Tveit (1972) Fra gull til grønne skoger (Oslo: Gyldendal Norsk Forlag) J.N. Tønnessen (1960) Norske Styrmandsforening i femti år, 1910-1960 (Oslo: Norsk Styrmandsforening)

P. Vogt (1938) Jerntid og jobbetid: En skildring av Norge under verdenskrigen (Oslo: Tanum)

I. Øvreseth, (1932) Vi som var våbenløse - en skibsførers erindringer fra krigstiden 1914-18 (Oslo: H. Aschehoug \& Co.)

R. Aaberge, A.B. Atkinson \& J. Modalsli (2016) 'On the measurement of longrun income inequality: Empirical evidence from Norway, 1875-2013', Discussion Paper 847 (Oslo: Statistics Norway)

Open Access This chapter is licensed under the terms of the Creative Commons Attribution-NonCommercial-NoDerivatives 4.0 International License (http:// creativecommons.org/licenses/by-nc-nd/4.0/), which permits any noncommercial use, sharing, distribution and reproduction in any medium or format, as long as you give appropriate credit to the original author(s) and the source, provide a link to the Creative Commons license and indicate if you modified the licensed material. You do not have permission under this license to share adapted material derived from this chapter or parts of it.

The images or other third party material in this chapter are included in the chapter's Creative Commons license, unless indicated otherwise in a credit line to the material. If material is not included in the chapter's Creative Commons license and your intended use is not permitted by statutory regulation or exceeds the permitted use, you will need to obtain permission directly from the copyright holder. 